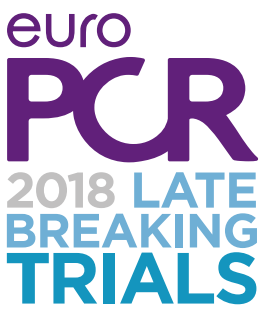

\title{
Biolimus A9 polymer-free coated stents in high bleeding risk patients undergoing complex PCl: evidence from the LEADERS FREE randomised clinical trial
}

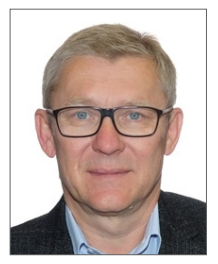

Janusz Lipiecki ${ }^{1}$, MD; Philippe Brunel2 ${ }^{2}$, MD; Marie-Claude Morice ${ }^{3}$, MD; Christan Roguelov ${ }^{4}, \mathrm{MD}$; Simon Walsh ${ }^{5}, \mathrm{MD}$; Gert Richardt ${ }^{6}, \mathrm{MD}$; Pedro Eerdmans ${ }^{7}, \mathrm{MD}$; Robaayah Zambahari ${ }^{8}, \mathrm{MD}$; Jacques Berland ${ }^{9}, \mathrm{MD}$; Samuel Copt ${ }^{10}, \mathrm{PhD}$; Hans-Peter Stoll ${ }^{10}, \mathrm{MD}$; Philip Urban ${ }^{11 *}$, MD

1. ELSAN, Pôle Santé République Centre de Cardiologie Interventionnelle, Clermont-Ferrand, France; 2. Hôpital Privé DijonBourgogne, Dijon, France; 3. Ramsay Générale de Santé, ICPS, Massy, France; 4. CHUV, Lausanne, Switzerland; 5. Belfast Health \& Social Care Trust, Belfast, Northern Ireland, United Kingdom; 6. Segeberger Kliniken, Herzzentrum, Bad Segeberg, Germany; 7. DEKRA, Arnhem, the Netherlands; 8. National Heart Institute, Kuala Lumpur, Malaysia; 9. Clinique Saint-Hilaire, Rouen, France; 10. Biosensors, Morges, Switzerland; 11. Hôpital de la Tour, Geneva, Switzerland

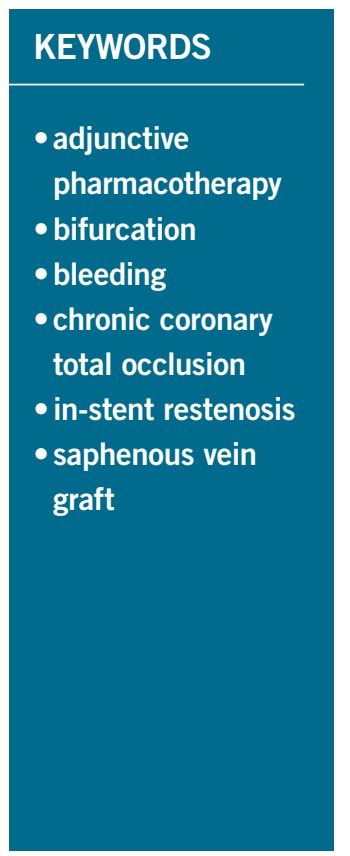

\begin{abstract}
Aims: The LEADERS FREE trial has demonstrated that a polymer-free Biolimus A9-coated stent (BA9DCS) is superior to a bare metal stent (BMS) for high bleeding risk (HBR) patients when treated with one month of dual antiplatelet therapy (DAPT). This analysis aimed to determine the impact of PCI procedure complexity on the two-year results.
\end{abstract}

Methods and results: Six hundred and sixty-seven (667) patients enrolled in the LEADERS FREE (BA9DCS 346, BMS 321) underwent a complex PCI, defined by one or more of eight characteristics: total stent length $\geq 60 \mathrm{~mm}, \geq 3$ vessels or lesions treated, $\geq 3$ stents implanted, bifurcation lesion treated with $\geq 2$ stents, chronically occluded, restenotic or saphenous vein graft lesion. Patients undergoing complex PCI were older, more often male, and presented with more ACS, diabetes, renal insufficiency, anaemia and multivessel disease. They derived major benefit from DCS over BMS for safety $(16.2 \%$ vs. $21.7 \%$, HR 0.70 [0.490.99 ], $\mathrm{p}<0.05)$ and for efficacy $(10.8 \%$ vs. $18.1 \%$, HR 0.54 [0.35-0.83], $\mathrm{p}<0.005)$. For the 1,746 patients with non-complex PCI, DCS demonstrated superior efficacy (5.3\% vs. 9.9\%, HR 0.52 [0.36-0.75], p $<0.001$, $\mathrm{p}$ for interaction NS) and similar safety to BMS (11.1\% vs. $12.6 \%$, NS, p for interaction NS).

Conclusions: Compared to BMS, the BA9-DCS maintained both efficacy and safety benefits when used in complex PCI procedures.

\footnotetext{
*Corresponding author: Hôpital de La Tour, Av. J.D. Maillard 3, 1217 Geneva, Switzerland. E-mail:philip.urban@latour.ch
} 


\section{Abbreviations}

BA9

BMS

DAPT

DCS

DES

HBR

MI

Biolimus A9

bare metal stent

dual antiplatelet therapy

drug-coated stent

drug-eluting stent

high bleeding risk

myocardial infarction

\section{Introduction}

When drug-eluting coronary stents (DES) were first given approval for clinical use, indications were limited and largely based on the inclusion and exclusion criteria of the early pivotal trials ${ }^{1,2}$. It then gradually became apparent that DES remained more effective than bare metal stents (BMS) for more complex "off-label" indications ${ }^{3,4}$. When improved DES became available and were compared to BMS, a safety benefit was also documented, all the more so in higher-risk indications such as acute myocardial infarction, or complex revascularisation procedures ${ }^{5-7}$.

The LEADERS FREE trial has documented improved safety and efficacy of a polymer-free drug-coated stent (DCS) when compared to a similar BMS for the treatment of patients at high bleeding risk (HBR) treated with dual antiplatelet therapy (DAPT) for one month only ${ }^{8-10}$. Whether polymer-free DCS are equally advantageous in HBR patients requiring complex PCI has not been studied. The current analysis of LEADERS FREE therefore focuses on the comparison of efficacy and safety of a polymer-free Biolimus A9 drug-coated stent (BA9-DCS) vs. a similar BMS in HBR patients who underwent a complex percutaneous coronary intervention (PCI) procedure, using a modification of the definition recently proposed by Giustino et $\mathrm{al}^{11}$.

\section{Editorial, see page 383}

\section{Methods}

\section{PATIENTS AND METHODS}

Two thousand four hundred and thirteen $(2,413)$ patients enrolled in LEADERS FREE with complete information defining PCI complexity were included. Methods and proceedings for LEADERS FREE have been described previously ${ }^{8-10}$ and are summarised here. LEADERS FREE is a randomised, double-blind clinical trial, which evaluated 2,432 patients at 68 sites in 20 countries. Patients were required to meet one or more of the criteria for an increased bleeding risk listed in Table 1. There were only a few exclusion criteria and, except for target vessel reference diameters $<2.25 \mathrm{~mm}$ or $>4 \mathrm{~mm}$, none was based on angiographic or procedure characteristics ${ }^{8}$. Patients were randomly assigned 1:1 to undergo PCI with a polymer-free BA9-DCS (BioFreedom $^{\mathrm{TM}}$ DCS; Biosensors Europe, Morges, Switzerland) or a similar bare metal stent (Gazelle ${ }^{\mathrm{TM}}$; Biosensors Interventional Technologies, Singapore). Randomisation was performed with the use of either a Web-based system or a telephone interactive voice-response system (Merge Healthcare Inc., Chicago, IL, USA [www.merge.com]) in blocks of 16 with no further stratification. All patients received one month of DAPT followed by single antiplatelet therapy lifelong. PCI was considered complex when at least one of eight criteria was satisfied (Table 2).

\section{STUDY PROCEEDINGS}

PCI was performed according to standard techniques. Decisions regarding vascular access site, periprocedural antithrombotic

Table 1. Trial inclusion criteria for complex and non-complex PCI subgroups.

\begin{tabular}{|c|c|c|c|c|c|c|c|c|}
\hline \multirow[b]{2}{*}{ Inclusion criteria } & \multicolumn{4}{|c|}{ Complex PCI (N=667) } & \multicolumn{4}{|c|}{ Non-complex PCI $(\mathrm{N}=1,746)$} \\
\hline & $\begin{array}{c}\text { BMS } \\
(\mathrm{N}=321)\end{array}$ & $\begin{array}{c}\text { DCS } \\
(\mathrm{N}=346)\end{array}$ & $\begin{array}{c}\text { Total } \\
(\mathrm{N}=667)\end{array}$ & $p$-value & $\begin{array}{c}\text { BMS } \\
(\mathrm{N}=880)\end{array}$ & $\begin{array}{c}\text { DCS } \\
(\mathrm{N}=866)\end{array}$ & $\begin{array}{c}\text { Total } \\
(\mathrm{N}=1,746)\end{array}$ & $p$-value \\
\hline Planned OAC after PCl & $105(32.7 \%)$ & $126(36.4 \%)$ & $231(34.6 \%)$ & 0.3149 & $323(36.7 \%)$ & $317(36.6 \%)$ & $640(36.7 \%)$ & 0.9656 \\
\hline Age $>75$ years & $220(68.5 \%)$ & $232(67.1 \%)$ & $452(67.8 \%)$ & 0.6820 & $549(62.4 \%)$ & $549(63.4 \%)$ & $1,098(62.9 \%)$ & 0.6627 \\
\hline $\begin{array}{l}\text { Haemoglobin }<11 \mathrm{~g} / \mathrm{dl} \text { or recent } \\
\text { transfusion }\end{array}$ & $68(21.2 \%)$ & $51(14.7 \%)$ & $119(17.8 \%)$ & 0.0299 & $123(14 \%)$ & $132(15.2 \%)$ & $255(14.6 \%)$ & 0.4542 \\
\hline Prior intracerebral bleed & $5(1.6 \%)$ & $1(0.3 \%)$ & $6(0.9 \%)$ & 0.0829 & $14(1.6 \%)$ & $13(1.5 \%)$ & $27(1.5 \%)$ & 0.8792 \\
\hline Stroke in the last year & $8(2.5 \%)$ & $3(0.9 \%)$ & $11(1.6 \%)$ & 0.0996 & $16(1.8 \%)$ & $12(1.4 \%)$ & $28(1.6 \%)$ & 0.4719 \\
\hline Admission for bleeding in last year & $11(3.4 \%)$ & $12(3.5 \%)$ & $23(3.4 \%)$ & 0.9766 & $20(2.3 \%)$ & $34(3.9 \%)$ & $54(3.1 \%)$ & 0.0460 \\
\hline Cancer in last 3 years* & $31(9.7 \%)$ & $33(9.5 \%)$ & $64(9.6 \%)$ & 0.9582 & $88(10 \%)$ & $85(9.8 \%)$ & $173(9.9 \%)$ & 0.8972 \\
\hline $\begin{array}{l}\text { Steroids/NSAID planned } \\
>30 \text { days post } \mathrm{PCl}\end{array}$ & $13(4 \%)$ & $11(3.2 \%)$ & $24(3.6 \%)$ & 0.5464 & $21(2.4 \%)$ & $26(3 \%)$ & $47(2.7 \%)$ & 0.4266 \\
\hline $\begin{array}{l}\text { Planned major surgery in } \\
\text { following year }\end{array}$ & $49(15.3 \%)$ & $56(16.2 \%)$ & $105(15.7 \%)$ & 0.7444 & $160(18.2 \%)$ & $130(15 \%)$ & $290(16.6 \%)$ & 0.0751 \\
\hline Creatinine clearance $<40 \mathrm{ml} / \mathrm{min}$ & $73(22.7 \%)$ & $70(20.2 \%)$ & $143(21.4 \%)$ & 0.4299 & $171(19.4 \%)$ & $147(17 \%)$ & $318(18.2 \%)$ & 0.1835 \\
\hline Platelets $<100,000 / \mathrm{mm}^{3}$ & $7(2.2 \%)$ & $6(1.7 \%)$ & $13(1.9 \%)$ & 0.6768 & $11(1.3 \%)$ & $14(1.6 \%)$ & $25(1.4 \%)$ & 0.5191 \\
\hline Severe chronic liver disease & $4(1.2 \%)$ & $3(0.9 \%)$ & $7(1 \%)$ & 0.6312 & $6(0.7 \%)$ & $7(0.8 \%)$ & $13(0.7 \%)$ & 0.7585 \\
\hline $\begin{array}{l}\text { Expected non-compliance for } \\
>30 \text { days DAPT }\end{array}$ & $13(4 \%)$ & $8(2.3 \%)$ & $21(3.1 \%)$ & 0.1991 & $34(3.9 \%)$ & $33(3.8 \%)$ & $67(3.8 \%)$ & 0.9540 \\
\hline
\end{tabular}


Table 2. Prevalence of complex PCI components*.

\begin{tabular}{|l|r|r|c|}
\hline \multicolumn{1}{|c|}{ PCI characteristic } & $\begin{array}{c}\text { DCS } \\
\text { N=346 }\end{array}$ & $\begin{array}{c}\text { BMS } \\
\text { N=321 }\end{array}$ & $\begin{array}{c}\text { All } \\
\text { N=667 }\end{array}$ \\
\hline $\begin{array}{l}\text { Total stent length } \\
\geq 60 \mathrm{~mm}\end{array}$ & $157(45.4 \%)$ & $132(41.1 \%)$ & $289(43.3 \%)$ \\
\hline$\geq 3$ vessels treated & $53(15.3 \%)$ & $52(16.2 \%)$ & $105(15.7 \%)$ \\
\hline$\geq 3$ lesions treated & $159(46.0 \%)$ & $156(48.6 \%)$ & $315(47.2 \%)$ \\
\hline$\geq 3$ stents implanted & $255(73.7 \%)$ & $242(75.4 \%)$ & $497(74.5 \%)$ \\
\hline $\begin{array}{l}\text { Bifurcation treated } \\
\text { with } \geq 2 \text { stents }\end{array}$ & $36(10.4 \%)$ & $37(11.5 \%)$ & $73(10.9 \%)$ \\
\hline $\begin{array}{l}\text { Chronic total occlusion } \\
\text { target lesion }\end{array}$ & $64(18.5 \%)$ & $57(17.8 \%)$ & $121(18.4 \%)$ \\
\hline $\begin{array}{l}\text { In-stent restenosis } \\
\text { target lesion }\end{array}$ & $30(8.7 \%)$ & $33(10.3 \%)$ & $63(9.4 \%)$ \\
\hline $\begin{array}{l}\text { Saphenous vein graft } \\
\text { target lesion }\end{array}$ & $18(5.2 \%)$ & $23(7.2 \%)$ & $41(6.1 \%)$ \\
\hline
\end{tabular}

*Not mutually exclusive. BMS: bare metal stent; DCS: drug-coated stent; $\mathrm{PCl}$ : percutaneous coronary intervention

regimen, and lesion preparation were left to the operator. All target lesions were treated with at least one study stent. Staged procedures were permitted within one week after the index procedure. The protocol mandated that all patients receive both aspirin and a $\mathrm{P} 2 \mathrm{Y}_{12}$ inhibitor for 30 days, followed by a single antiplatelet agent. Per protocol, patients who were included in the trial because of planned oral anticoagulation post PCI could receive either triple therapy for one month or the WOEST regimen ${ }^{12}$.

A patient follow-up visit on site was performed at 30 days and 365 days. Further contacts were made at 60, 120 and 730 days. Ischaemia testing and angiographic evaluation during follow-up were left to the discretion of the investigator.

\section{STUDY ENDPOINTS}

For this subgroup analysis, the primary safety endpoint (cumulative incidence of a composite of cardiac death, myocardial infarction, or definite or probable stent thrombosis) and the primary efficacy endpoint (incidence of clinically driven target lesion revascularisation) of the main trial were both assessed at two years.

Bleeding events were also recorded during the same period. Myocardial infarction was defined according to the third universal definition of myocardial infarction ${ }^{13}$, stent thrombosis according to the ARC definitions ${ }^{14}$, and bleeding according to the BARC definitions ${ }^{15}$. To allow comparison with other series, the rate of coronary thrombotic events (myocardial infarction and/or definite or probable stent thrombosis) was recorded at one year. Clinically driven target lesion revascularisation was defined as PCI or surgery either for operator-defined restenosis in the treated lesion together with angina symptoms or documented ischaemia, or for a core laboratory-defined restenosis of greater than $70 \%$ of the artery diameter without symptoms or ischaemia.

\section{STATISTICAL ANALYSIS}

Continuous variables are presented as mean $\pm \mathrm{SD}$, categorical data as counts and percentages. Categorical variables were compared using a chi-square test; continuous variables were compared using a two-sample t-test. Whenever appropriate, a Fisher's exact test was used instead. For time-to-event variables, a hazard ratio and its $95 \%$ confidence interval were derived from an unadjusted Cox proportional hazards model. Cumulative incidence rates come from the Kaplan-Meier estimator with log-rank p-value to test whether the plots differed over time. Proportional hazards assumptions were checked using Schoenfeld residuals. P-values for interaction were derived using a likelihood ratio test. There was no imputation for missing data. All available data were used in the analysis of all endpoints. All data were analysed using SAS, v9.4 (SAS Institute Inc., Cary, NC, USA).

\section{Results}

\section{PATIENTS AND PROCEDURES}

Six hundred and sixty-seven (667) patients in LEADERS FREE underwent a complex PCI procedure (Figure 1). Of these, 346 were assigned to the BA9-DCS and 321 to the BMS.

The trial inclusion criteria for the complex and non-complex PCI groups are shown in Table 1. They were well balanced except for anaemia or recent transfusion that was more frequent for BMS in the complex PCI group, and must represent the play of chance. Baseline clinical characteristics for complex and non-complex patients are displayed in Table 3. The complex PCI patient population was older, suffered from more comorbid conditions and more often had multivessel coronary disease.

The PCI characteristics that defined the complex group are shown in Table 2, and further procedure characteristics of this group are given in Table 4.

For complex PCI patients, at 23 days, DAPT was used in the DCS and BMS groups in $93.0 \%$ and $96.2 \%$, respectively $(\mathrm{p}=0.07$ ). In detail, ASA was given in $100 \%$ and $100 \%$, clopidogrel in $90.6 \%$ and $91.4 \%$, ticagrelor in $7.6 \%$ and $5.3 \%$, and prasugrel in $1.9 \%$ and $3.0 \%$, respectively. At 37 days, DAPT was continued in 34 patients $(10.1 \%)$ in the DCS arm and $43(13.8 \%)$ in the BMS arm $(\mathrm{p}=0.14)$. For non-complex PCI patients, at 23 days, DAPT was used in the DCS and BMS groups in $96.3 \%$ and $94.7 \%$, respectively $(\mathrm{p}=0.13)$. In detail, ASA was given in $100 \%$ and $100 \%$, clopidogrel in $94.0 \%$ and $94.7 \%$, ticagrelor in $4.9 \%$ and $4.4 \%$, and prasugrel in $1.0 \%$ and $1.0 \%$, respectively. At 37 days, DAPT was continued in 70 patients $(8.3 \%)$ in the DCS arm and 70 $(8.1 \%)$ in the BMS arm $(p=0.88)$.

\section{PRIMARY ENDPOINTS}

At two years in the complex PCI group, the primary efficacy endpoint (clinically driven target lesion revascularisation) had occurred in 34 patients $(10.8 \%)$ in the DCS group and 53 patients $(18.1 \%$ ) in the BMS group (HR 0.54, 95\% CI: 0.35 $0.83 ; \mathrm{p}<0.005$ ). The primary safety endpoint (composite of cardiac death, myocardial infarction, or definite or probable stent thrombosis) had occurred in 54 patients $(16.2 \%)$ in the DCS group and in 68 patients $(21.7 \%)$ in the BMS group (HR 0.70, 95\% CI: 0.49-0.99; $\mathrm{p}<0.05$ ) (Table 5). The time-to-event curves 


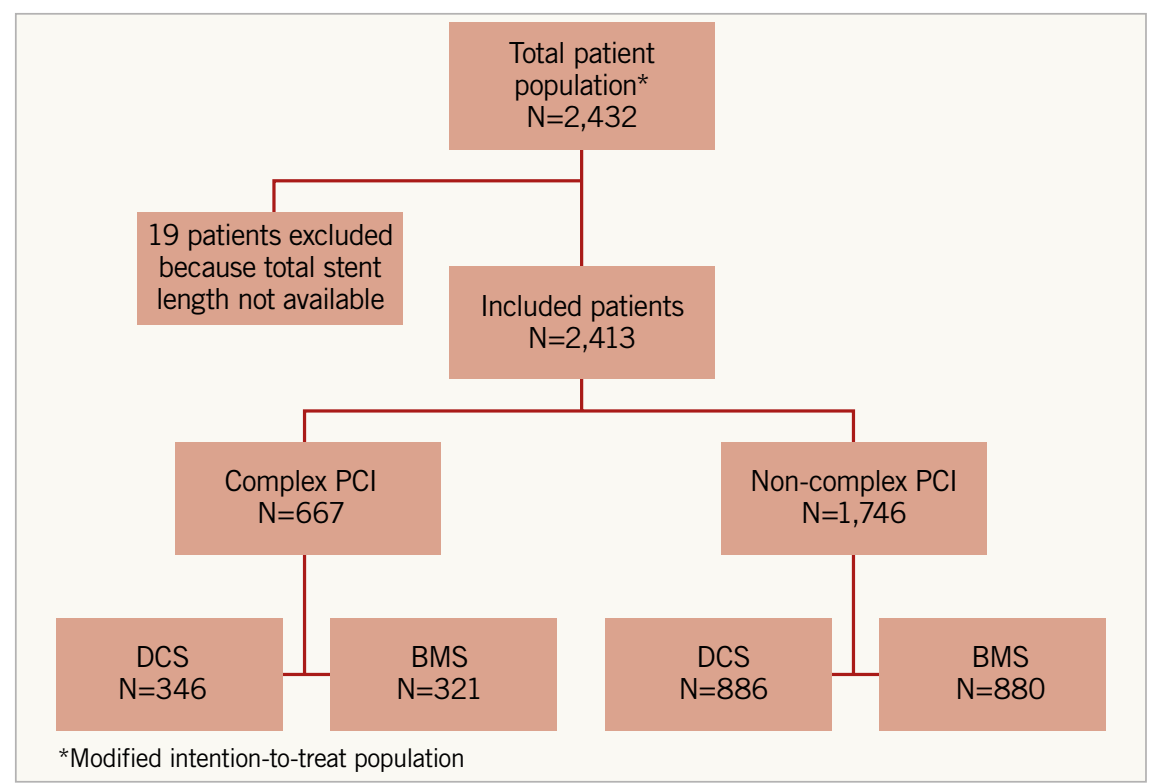

Figure 1. LEADERS FREE complex procedure flow chart.

Table 3. Baseline characteristics for complex and non-complex PCI subgroups.

\begin{tabular}{|c|c|c|c|c|c|c|c|}
\hline & $\begin{array}{l}\text { Complex } \\
\text { PCI - DCS }\end{array}$ & $\begin{array}{l}\text { Complex } \\
\text { PCI - BMS }\end{array}$ & $\begin{array}{l}\text { Complex PCI } \\
\text { all }\end{array}$ & $\begin{array}{l}\text { Non-complex } \\
\text { PCI - DCS }\end{array}$ & $\begin{array}{c}\text { Non-complex } \\
\text { PCI - BMS }\end{array}$ & $\begin{array}{l}\text { Non-complex } \\
\text { PCI all }\end{array}$ & $\begin{array}{l}p \text {-value (complex } \\
\text { vs. non-complex) }\end{array}$ \\
\hline Mean age (years) & $76.3 \pm 9.2$ & $76.8 \pm 8.4$ & $76.5 \pm 8.8$ & $75.4 \pm 9.4$ & $75.2 \pm 9.6$ & $75.3 \pm 9.5$ & 0.006 \\
\hline Female gender & $90(26.0 \%)$ & $86(26.8 \%)$ & $176(26.4)$ & $273(31.5 \%)$ & $286(32.5 \%)$ & $559(32.0 \%)$ & 0.007 \\
\hline ACS presentation & 89 (25.7\%) & $111(34.6 \%)$ & $200(30.0 \%)$ & $239(27.6 \%)$ & $213(24.2 \%)$ & $452(25.9 \%)$ & 0.043 \\
\hline Diabetes & $125(36.3 \%)$ & $116(36.3 \%)$ & $241(36.3 \%)$ & $286(33.1 \%)$ & $271(30.8 \%)$ & $557(31.9 \%)$ & 0.042 \\
\hline Renal insufficiency & $90(26.2 \%)$ & $82(25.6 \%)$ & $172(25.9 \%)$ & $154(17.8 \%)$ & $195(22.3 \%)$ & $349(20.1 \%)$ & 0.002 \\
\hline Prior coronary revascularisation & $96(28.0 \%)$ & $99(31.1 \%)$ & $195(29.5 \%)$ & $195(22.7 \%)$ & $222(25.3 \%)$ & $417(24.3 \%)$ & 0.006 \\
\hline Anaemia or recent transfusion & $51(14.7 \%)$ & $68(21.2 \%)$ & $119(17.8 \%)$ & $132(15.2 \%)$ & $123(14 \%)$ & $255(14.6 \%)$ & 0.0495 \\
\hline $\begin{array}{l}\text { Mean number of trial inclusion } \\
\text { criteria }\end{array}$ & $1.77 \pm 0.92$ & $1.89 \pm 0.96$ & $1.83 \pm 0.95$ & $1.73 \pm 0.88$ & $1.75 \pm 0.86$ & $1.73 \pm 0.86$ & 0.03 \\
\hline Multivessel disease & $283(83.2 \%)$ & $267(85 \%)$ & $550(84.1 \%)$ & $465(54.6 \%)$ & $465(53.1 \%)$ & $930(53.9 \%)$ & $<0.0001$ \\
\hline Staged index procedure & $48(12.2 \%)$ & $60(15.7 \%)$ & $108(13.9 \%)$ & $16(1.8 \%)$ & $9(1 \%)$ & $25(1.4 \%)$ & $<0.0001$ \\
\hline
\end{tabular}

Table 4. Procedure characteristics for the complex PCI group.

\begin{tabular}{|l|c|c|c|}
\hline Radial access & DCS & BMS & $\boldsymbol{p}$-value \\
\hline Staged procedure & $204(51.8 \%)$ & $208(54.6 \%)$ & 0.43 \\
\hline $\begin{array}{l}\text { Mean number of treated } \\
\text { lesions/patient }\end{array}$ & $2.4 \pm 1.1$ & $2.5 \pm 1.2$ & 0.10 \\
\hline $\begin{array}{l}\text { Mean number of treated } \\
\text { vessels/patient }\end{array}$ & $1.7 \pm 0.7$ & $1.8 \pm 0.7$ & 0.18 \\
\hline $\begin{array}{l}\text { Mean number of } \\
\text { implanted stents/patient }\end{array}$ & $3.1 \pm 1.3$ & $3.2 \pm 1.4$ & 0.59 \\
\hline $\begin{array}{l}\text { Total length of implanted } \\
\text { stents/patient, mm }\end{array}$ & $58.8 \pm 26.8$ & $59.2 \pm 29.0$ & 0.87 \\
\hline $\begin{array}{l}\text { Mean stent nominal } \\
\text { diameter, mm }\end{array}$ & $2.7 \pm 0.4$ & $2.7 \pm 0.4$ & 0.73 \\
\hline BMS: bare metal stent; DCS: drug-coated stent \\
\hline
\end{tabular}

for the primary efficacy and safety endpoints for both the complex and the non-complex PCI groups are shown in Figure 2. For the complex PCI patients, coronary thrombotic events (MI and/or definite or probable stent thrombosis) at one year had occurred in $17.3 \%$ of BMS and $11.2 \%$ of DCS patients $(\mathrm{p}<0.02)$. Compared to patients enrolled after non-complex PCI procedures, both adverse event rates and the absolute reduction in safety and efficacy events associated with use of the DCS were greater after complex PCI procedures; however, the p-values for interaction were non-significant, suggesting that both groups of patients behaved in a similar fashion (Table 5). Only for definite or probable stent thrombosis did the DCS appear to be associated with a significantly greater benefit in the complex vs. the noncomplex PCI group ( $\mathrm{p}$ for interaction=0.0104). 
Table 5. Safety and efficacy endpoints (two years).

\begin{tabular}{|c|c|c|c|c|c|c|c|c|c|}
\hline \multirow{2}{*}{ Parameter } & \multicolumn{4}{|c|}{ Complex PCI (N=667) } & \multicolumn{4}{|c|}{ Non-complex PCI $(\mathrm{N}=1,746)$} & \multirow{2}{*}{$\begin{array}{c}\text { Interaction } \\
p \text {-value }\end{array}$} \\
\hline & BMS $(N=321)$ & $\operatorname{DCS}(\mathrm{N}=346)$ & Hazard ratio & $p$-value & BMS $(N=880)$ & DCS $(N=866)$ & Hazard ratio & $p$-value & \\
\hline Primary safety endpoint & $68(21.69 \%)$ & $54(16.17 \%)$ & $0.695(0.486: 0.993)$ & 0.0449 & $108(12.64 \%)$ & $92(11.1 \%)$ & $0.863(0.653: 1.139)$ & 0.2967 & 0.3401 \\
\hline Cardiac death & $27(8.57 \%)$ & $23(6.98 \%)$ & $0.764(0.438: 1.333)$ & 0.3430 & $52(6.19 \%)$ & $52(6.4 \%)$ & $1.022(0.696: 1.5)$ & 0.9133 & 0.3967 \\
\hline Myocardial infarction & $50(16.39 \%)$ & $36(10.87 \%)$ & $0.633(0.413: 0.972)$ & 0.0351 & $64(7.56 \%)$ & $54(6.54 \%)$ & $0.856(0.596: 1.229)$ & 0.3973 & 0.2870 \\
\hline $\begin{array}{l}\text { Definite or probable stent } \\
\text { thrombosis }\end{array}$ & $15(4.77 \%)$ & $6(1.79 \%)$ & $0.364(0.141: 0.938)$ & 0.0291 & $12(1.41 \%)$ & $19(2.24 \%)$ & $1.621(0.787: 3.34)$ & 0.1857 & 0.0104 \\
\hline $\begin{array}{l}\text { Composite of definite or } \\
\text { probable ST or MI }\end{array}$ & $53(17.3 \%)$ & $37(11.16 \%)$ & $0.615(0.404: 0.935)$ & 0.0218 & $67(7.9 \%)$ & $59(7.1 \%)$ & $0.893(0.629: 1.267)$ & 0.5251 & 0.4828 \\
\hline $\begin{array}{l}\text { Clinically driven target lesion } \\
\text { revascularisation }\end{array}$ & $53(18.1 \%)$ & 34 (10.77\%) & $0.542(0.352: 0.834)$ & 0.0047 & $82(9.85 \%)$ & $43(5.27 \%)$ & $0.522(0.361: 0.754)$ & 0.0004 & 0.8823 \\
\hline BARC bleeding & 70 (23.44\%) & 77 (22.84\%) & $1.018(0.736: 1.407)$ & 0.9149 & 186 (21.83\%) & $179(21.62 \%)$ & $0.97(0.79: 1.191)$ & 0.7718 & 0.8111 \\
\hline BARC bleeding 2-5 & $58(19.55 \%)$ & $64(18.96 \%)$ & $1.023(0.717: 1.46)$ & 0.9000 & 146 (17.22\%) & $139(16.83 \%)$ & $0.962(0.762: 1.213)$ & 0.7407 & 0.7837 \\
\hline BARC bleeding 3-5 & $34(11.53 \%)$ & $33(9.78 \%)$ & $0.881(0.546: 1.422)$ & 0.6043 & $70(8.31 \%)$ & 72 (8.73\%) & $1.053(0.758: 1.463)$ & 0.7595 & 0.5355 \\
\hline
\end{tabular}

A
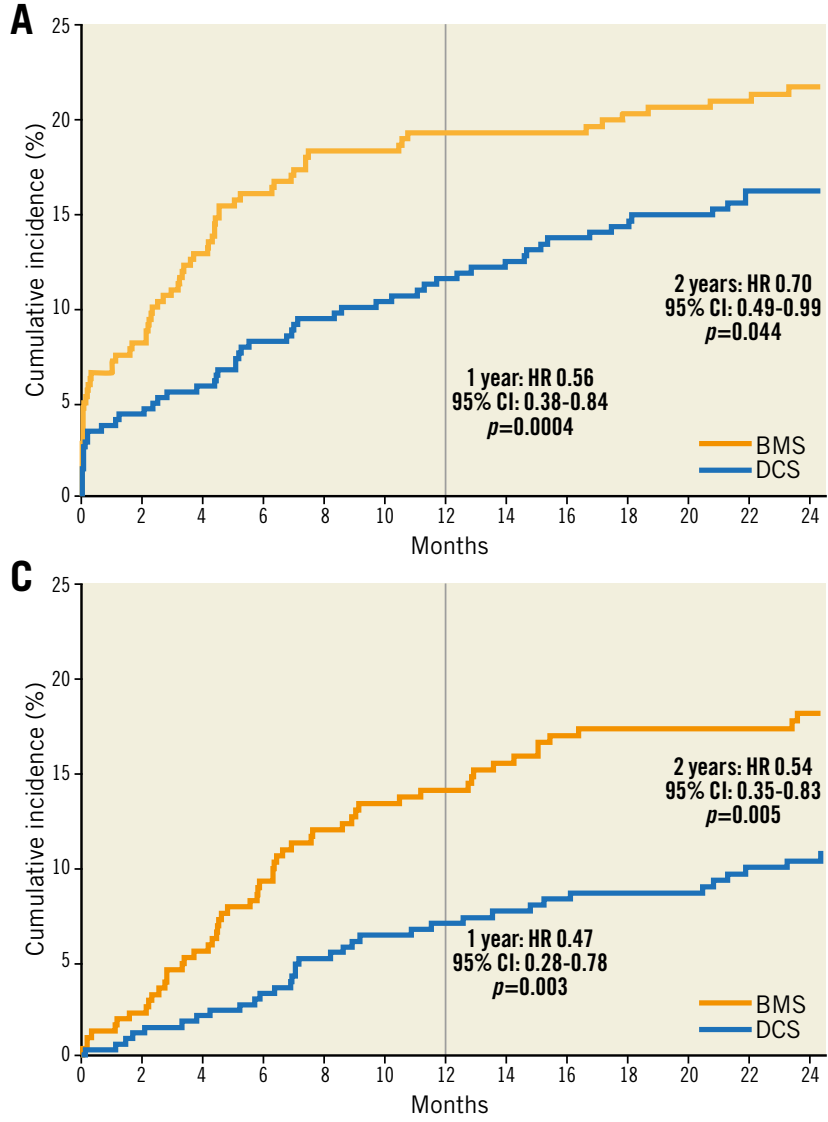
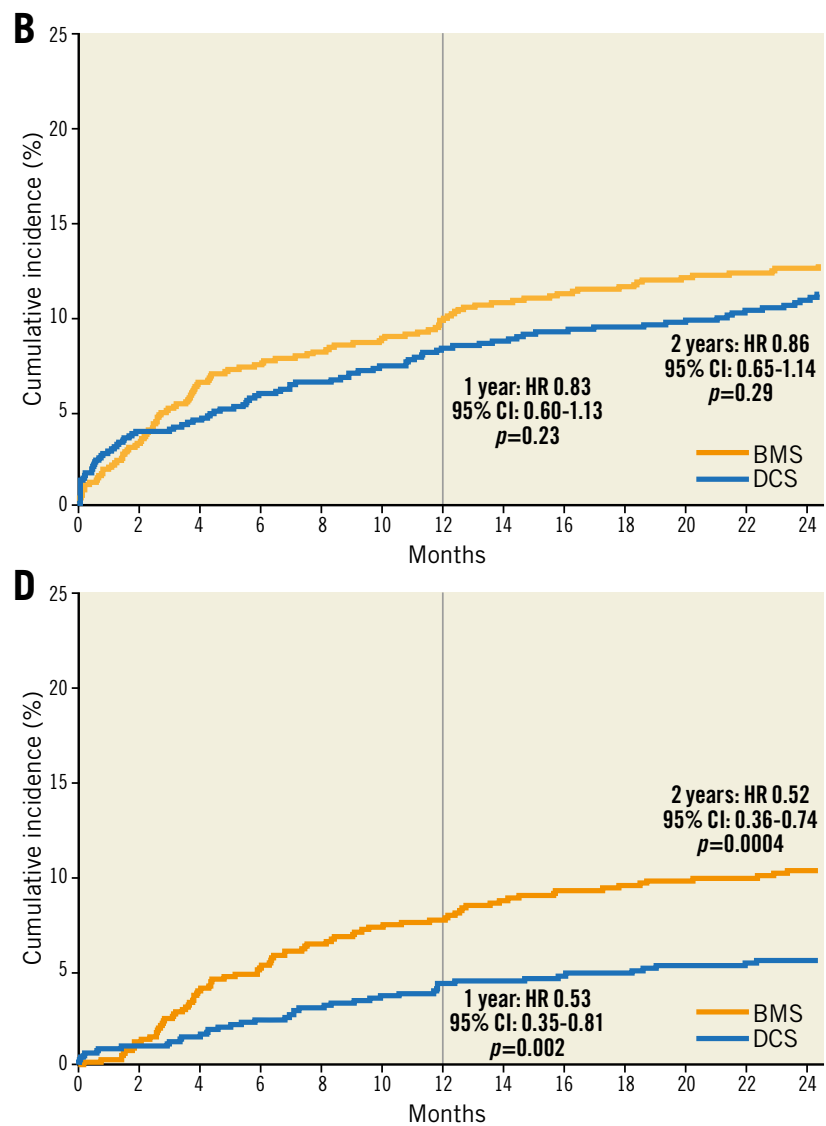

Figure 2. Time-to-event curves for the composite safety endpoint of cardiac death, myocardial infarction or definite and probable stent thrombosis (A: complex PCI group, B: non-complex PCI group) and for the efficacy endpoint of clinically driven target lesion revascularisation (C: complex PCI group, D: non-complex PCI group).

\section{Discussion}

The main findings of the present analysis are as follows: 1) HBR patients appear to require complex PCI more often than all-comer patients enrolled in randomised controlled trials ${ }^{4}$; 2) adverse events were markedly more frequent after complex vs. non-complex PCI (Table 5); 3) while the p-values for interaction were non-significant, HBR patients undergoing complex PCI were those who derived the greatest absolute safety and efficacy benefit from the use of a DCS rather than a BMS (Table 5, Figure 2). 
After DES were first approved for simple PCI procedures ${ }^{1,2}$, their use was evaluated for more complex procedures and for a variety of clinical presentations ${ }^{3,6}$. Complex PCI has long been recognised as a risk factor for adverse thrombotic events, both in randomised trials of all-comer patients and in large registries, and the benefits of improved stent platforms, implantation techniques and adjunct pharmacology have usually been more apparent in such patients ${ }^{11,16-22}$.

In a pooled analysis of six randomised trials comparing $\geq 12$ months versus 3 or 6 months DAPT in 9,577 patients undergoing PCI, Giustino et $\mathrm{al}^{11}$ found that the 1,680 patients who underwent complex PCI suffered an increased rate of major adverse cardiac events compared to non-complex PCI $(5.4 \%$ vs. $2.9 \%$; adjusted HR 1.98, 95\% CI: 1.50-2.60) after a median follow-up of 392 days. Also, the use of 12 rather than 3 to 6 months DAPT was associated with a reduction in major adverse cardiac events in the complex PCI group (4.1\% vs. $6.8 \%$; adjusted HR $0.56,95 \%$ CI: $0.35-0.89)$ compared with the non-complex group (adjusted HR 1.01, 95\% CI: 0.75-1.35; p for interaction=0.01). The increased risk for major bleeding with prolonged DAPT was similar between groups ( $\mathrm{p}$ for interaction=0.96).

In the DAPT trial ${ }^{16}, 8,381$ enrolled subjects with complex target lesions had higher rates of MI or stent thrombosis in the first 12 months on DAPT after PCI than patients with non-complex lesions $(3.9 \%$ vs. $2.4 \%$; $<0.001)$, but the benefit of prolonged DAPT beyond 12 months was similar for the complex and the non-complex groups.

Both the definition of complex PCI and differing patient selection criteria probably explain the higher safety event rates that were observed in our series compared to those reported by Giustino and $\mathrm{Yeh}^{11,16}$. In the DAPT trial, "complex" was based solely on lesion characteristics (unprotected left main, $>2$ lesions/vessel, length $\geq 30 \mathrm{~mm}$, bifurcation with side branch $\geq 2.5 \mathrm{~mm}$, vein bypass graft, or thrombus-containing lesion) and therefore probably included a share of less complex situations. Our own definition is an extended version of that proposed by Giustino et al and used in the recent update of the ESC guidelines ${ }^{11,23}$, and includes PCI for in-stent restenosis and for lesions located in saphenous vein grafts. Both of these are well recognised to carry an increased thrombotic risk $^{20,21}$ but because such locations were exclusion criteria in the six trials composing Giustino's pooled analysis they could not be assessed in that analysis.

Considering patient selection, both Giustino and Yeh report on complex procedures in otherwise low- to medium-risk all-comer patients enrolled in randomised controlled trials with numerous exclusion criteria, several of which (such as anaemia, recent bleeding, need for long-term anticoagulation or planned major surgery) were inclusion criteria for LEADERS FREE. It is thus not surprising that coronary thrombotic events were more frequent in our series (11.2\% and $17.3 \%$ for DCS and BMS, respectively, at one year vs. $3.9 \%$ during the first year in the DAPT trial and $4.2 \%$ in Giustino et al's analysis). Confirming that the populations studied were indeed very different, the observed major bleeding rates were also very different among the three series of complex PCI or complex lesions at one year: 9.3\% BARC 3-5 for LEADERS FREE, 1.0\% with a mix of several definitions for Giustino et al, and $2.2 \%$ BARC 3 or 5 for the DAPT trial.

A major remaining problem is the concomitant higher risk of both thrombotic and bleeding events of HBR patients following complex PCI (Table 5); the important question of the optimal DAPT duration for different subsets of HBR patients thus remains open. LEADERS FREE compared two stents using the 2012 guideline-endorsed minimal standard DAPT duration after BMS implantation ${ }^{24}$. Giustino showed that prolonging DAPT beyond the first six months was associated with fewer thrombotic events but more bleeding after complex PCI with DES for allcomer patients. One can hypothesise that a DAPT course longer than 30 days could have reduced the adverse thrombotic event rates after complex PCI for some of the LEADERS FREE HBR patients, but at the cost of an increase in the already high bleeding rate. Clearly, only a randomised trial targeted at this specific population would be capable of assessing the risks and benefits of different DAPT durations after DCS implantation.

\section{Limitations}

Because these results are based on a post hoc analysis of a trial subgroup, they should be considered only as hypothesis-generating. However, the data strongly suggest that complex PCI truly constitutes a very high-risk subset that derives major benefit from DCS vs. BMS.

Use of the SYNTAX score would have been of interest and might have had a comparable or superior discrimination power in defining a patient subset at particularly high risk of thrombotic events, but this information was not available in our database $\mathrm{e}^{25}$.

LEADERS FREE compared the combination of one-month DAPT with implantation of a BA9-DCS vs. a BMS. The results cannot be extended to other devices or treatment regimens.

\section{Conclusions}

We believe that these results reinforce the conclusions of the LEADERS FREE trial. Compared to BMS, the BA9-DCS maintained both its efficacy and its safety benefits when used in complex PCI procedures. There is no place today for BMS, except when the choice is driven by economic considerations.

\section{Impact on daily practice}

The LEADERS FREE trial has previously shown that a BA9DCS is superior to a BMS both for safety and for efficacy when compared to a BMS in patients at high bleeding risk and treated with only one month of DAPT. The current analysis is the first to show that the BA9-DCS maintains both its safety and its efficacy advantage over a BMS when used for patients undergoing complex PCI procedures. Whether such patients would benefit from a course of DAPT extending beyond one month deserves further study. 


\section{Acknowledgements}

The authors wish to acknowledge the contribution of Ute Windhövel, PhD (CERC, Massy, France), for her excellent work in the management of this study.

\section{Funding}

The LEADERS FREE trial was fully funded by Biosensors Europe.

\section{Conflict of interest statement}

S. Copt and H-P. Stoll are full-time employees of Biosensors. P. Urban and J. Lipiecki are paid consultants to Biosensors. $\mathrm{M}-\mathrm{C}$. Morice is the CEO of CERC, the organisation that conducted the trial. The other authors have no conflicts of interest to declare.

\section{References}

1. Moses JW, Leon MB, Popma JJ, Fitzgerald PJ, Holmes DR, O'Shaughnessy C, Caputo RP, Kereiakes DJ, Williams DO, Teirstein PS, Jaeger JL, Kuntz RE; SIRIUS Investigators. Sirolimuseluting stents versus standard stents in patients with stenosis in a native coronary artery. $N$ Engl J Med. 2013;349:1315-23.

2. Stone GW, Ellis SG, Cox DA, Hermiller J, O’Shaughnessy C, Mann JT, Turco M, Caputo R, Bergin P, Greenberg J, Popma JJ, Russell ME; TAXUS-IV Investigators. One-year clinical results with the slow release, polymer-based, paclitaxel-eluting TAXUS stent: the TAXUS-IV trial. Circulation. 2004;109:1942-7.

3. Abbott JD, Voss, MR, Nakamura M, Cohen HA, Selzer F, Kip KE, Vlachos HA, Wilensky RL, Williams DO. Unrestricted use of drug-eluting stents compared with bare-metal stents in routine clinical practice: findings from the National Heart, Lung, and Blood Institute Dynamic Registry. J Am Coll Cardiol. 2007;50:2029-36.

4. James SK, Stenestrand U, Lindbäck J, Carlsson J, Scherstén F, Nilsson T, Wallentin, Lagerqvist B; SCAAR Study Group. Longterm safety and efficacy of drug-eluting versus bare-metal stents in Sweden. N Engl J Med. 2009;360:1933-45.

5. Räber L, Kelbæk H, Ostojic M, Baumbach A, Heg D, Tüller D, von Birgelen C, Roffi M, Moschovitis A, Khattab AA, Wenaweser P, Bonvini R, Pedrazzini G, Kornowski R, Weber K, Trelle S, Lüscher TF, Taniwaki M, Matter CM, Meier B, Jüni P, Windecker S; COMFORTABLE AMI Trial Investigators. Effect of biolimus-eluting stents with biodegradable polymer vs. bare-metal stents on cardiovascular events among patients with acute myocardial infarction: the COMFORTABLE AMI randomized trial. JAMA. 2012;308:777-87.

6. Sabate M, Cequier A, Iñiguez A, Serra A, HernandezAntolin R, Mainar V, Valgimigli M, Tespili M, den Heijer P, Bethencourt A, Vazquez N, Gómez-Hospital JA, Baz JA, MartinYuste V, van Geuns RJ, Alfonso F, Bordes P, Tebaldi M, Masotti M, Silvestro A, Backx B, Brugaletta S, van Es GA, Serruys PW. Everolimus-eluting stent versus bare-metal stent in ST-segment elevation myocardial infarction (EXAMINATION): 1 year results of a randomised controlled trial. Lancet. 2012;380:1482-90.

7. Palmerini T, Biondi-Zoccai G, Della Riva D, Stettler C, Sangiorgi D, D’Ascenzo F, Kimura T, Briguori C, Sabatè M,
Kim HS, De Waha A, Kedhi E, Smits PC, Kaiser C, Sardella G, Marullo A, Kirtane AJ, Leon MB, Stone GW. Stent thrombosis with drug-eluting and bare-metal stents: evidence from a comprehensive network meta-analysis. Lancet. 2012;379:1393-402.

8. Urban P, Abizaid A, Chevalier B, Greene S, Meredith I, Morice MC, Pocock S. Rationale and design of the LEADERS FREE trial: A randomized double-blind comparison of the BioFreedom drug-coated stent vs the Gazelle bare metal stent in patients at high bleeding risk using a short (1 month) course of dual antiplatelet therapy. Am Heart J. 2013;165:704-9.

9. Urban P, Meredith IT, Abizaid A, Pocock SJ, Carrié D, Naber C, Lipiecki J, Richardt G, Iñiguez A, Brunel P, ValdesChavarri M, Garot P, Talwar S, Berland J, Abdellaoui M, Eberli F, Oldroyd K, Zambahari R, Gregson J, Greene S, Stoll HP, Morice MC; LEADERS FREE Investigators. Polymer-free DrugCoated Coronary Stents in Patients at High Bleeding Risk. N Engl J Med. 2015;373:2038-47.

10. Garot P, Morice MC, Tresukosol D, Pocock SJ, Meredith IT, Abizaid A, Carrié D, Naber C, Iñiguez A, Talwar S, Menown IBA, Christiansen EH, Gregson J, Copt S, Hovasse T, Lurz P, Maillard L, Krackhardt F, Ong P, Byrne J, Redwood S, Windhövel U, Greene S, Stoll HP, Urban P. Two-Year Outcomes of High Bleeding Risk Patients after Polymer-Free Drug-Coated Stents. J Am Coll Cardiol. 2017;69:162-71.

11. Giustino G, Chieffo A, Palmerini T, Valgimigli M, Feres F, Abizaid A, Costa RA, Hong MK, Kim BK, Jang Y, Kim HS, Park KW, Gilard M, Morice MC, Sawaya F, Sardella G, Genereux P, Redfors B, Leon MB, Bhatt DL, Stone GW, Colombo A. Efficacy and safety of dual antiplatelet therapy after complex PCI. J Am Coll Cardiol. 2016;68:1851-64.

12. Dewilde WJ, Oirbans T, Verheugt FW, Kelder JC, De Smet BJ, Herrman JP, Adrianssens T, Vrolix M, Heestermans AA, Vis MM, Tijsen JG, van't Hof AW, ten Berg JM; WOEST study investigators. Use of clopidogrel with or without aspirin in patients taking oral anticoagulant therapy and undergoing percutaneous coronary intervention: an open-label, randomised, controlled trial. Lancet. 2013;381:1107-15.

13. Thygesen K, Alpert JS, Jaffe AS, Simoons ML, Chaitman BR, White HD; Writing Group on the Joint ESC/ACCF/AHA/WHF Task Force for the Universal Definition of Myocardial Infarction, Thygesen K, Alpert JS, White HD, Jaffe AS, Katus HA, Apple FS, Lindahl B, Morrow DA, Chaitman BA, Clemmensen PM, Johanson P, Hod H, Underwood R, Bax JJ, Bonow RO, Pinto F, Gibbons RJ, Fox KA, Atar D, Newby LK, Galvani M, Hamm CW, Uretsky BF, Steg PG, Wijns W, Bassand JP, Menasché P, Ravkilde J, Ohman EM, Antman EM, Wallentin LC, Armstrong PW, Simoons ML, Januzzi JL, Nieminen MS, Gheorghiade M, Filippatos G, Luepker RV, Fortmann SP, Rosamond WD, Levy D, Wood D, Smith SC, Hu D, Lopez-Sendon JL, Robertson RM, Weaver D, Tendera M, Bove AA, Parkhomenko AN, Vasilieva EJ, Mendis S; ESC Committee for Practice Guidelines (CPG). Third universal definition of myocardial infarction. Eur Heart $J$. 2012;33:2551-67. 
14. Cutlip DE, Windecker S, Mehran R, Boam A, Cohen DJ, van Es GA, Steg PG, Morel MA, Mauri L, Vranckx P, McFadden E, Lansky A, Hamon M, Krucoff MW, Serruys PW; Academic Research Consortium. Clinical end points in coronary stent trials: a case for standardized definitions. Circulation. 2007;115:2344-51.

15. Mehran R, Rao SV, Bhatt DL, Gibson CM, Caixeta A, Eikelboom J, Kaul S, Wiviott SD, Menon V, Nikolsky E, Serebruany V, Valgimigli M, Vranckx P, Taggart D, Sabik JF, Cutlip DE, Krucoff MW, Ohman EM, Steg PG, White H. Standardized bleeding definitions for cardiovascular clinical trials: a consensus report from the Bleeding Academic Research Consortium. Circulation. 2011;123:2736-47.

16. Yeh RW, Kereiakes DJ, Steg PG, Cutlip DE, Croce KJ, Massaro JM, Mauri L; DAPT Study Investigators. Lesion Complexity and Outcomes of Extended Dual Antiplatelet Therapy After Percutaneous Coronary Intervention. J Am Coll Cardiol. 2017;70: 2213-23.

17. Suh J, Park DW, Lee JY, Jung IH, Lee SW, Kim YH, Lee CW, Cheong SS, Kim JJ, Park SW, Park SJ. The relationship and threshold of stent length with regard to risk of stent thrombosis after drug-eluting stent implantation. JACC Cardiovasc Interv. 2010;3:383-9.

18. Brilakis ES, Banerjee S, Karmpaliotis D, Lombardi WL, Tsai TT, Shunk KA, Kennedy KF, Spertus JA, Holmes DR Jr, Grantham JA. Procedural outcomes of chronic total occlusion percutaneous coronary intervention: a report from the NCDR (National Cardiovascular Data Registry). JACC Cardiovasc Interv. 2015;8: 245-53.

19. Urban P, Gershlick AH, Guagliumi G, Guyon P, Lotan C, Schofer J, Seth A, Sousa JE, Wijns W, Berge C, Deme M, Stoll HP; e-Cypher Investigators. Safety of coronary sirolimus-eluting stents in daily clinical practice. Circulation. 2006;113:1434-41.

20. Campo G, Tebaldi M, Vranckx P, Biscaglia S, Tumscitz C, Ferrari R, Valgimigli M. Short versus long-term duration of dual antiplatelet therapy in patients treated for in-stent restenosis. $J \mathrm{Am}$ Coll Cardiol. 2014;63:506-12.
21. Sachdeva A, Bavisetty S, Beckham G, Shen AY, Aharonian V, Mansukhani P, Stone GW, Leon M, Moses J, Moore N, Hyett R, Contreras R, Brar SS. Discontinuation of long-term clopidogrel therapy is associated with death and myocardial infarction after saphenous vein graft percutaneous coronary intervention. $\mathrm{J} \mathrm{Am} \mathrm{Coll}$ Cardiol. 2012;60:2357-63.

22. Serruys PW, Morice MC, Kappetein AP, Colombo A, Holmes DR, Mack MJ, Ståhle E, Feldman TE, van den Brand M, Bass EJ, Van Dyck N, Leadley K, Dawkins KD, Mohr FW; SYNTAX Investigators. Percutaneous coronary intervention versus coronary-artery bypass grafting for severe coronary artery disease. N Engl J Med. 2009;360:961-72.

23. Valgimigli M, Bueno H, Byrne RA, Collet JP, Costa F, Jeppsson A, Jüni P, Kastrati A, Kolh P, Mauri L, Montalescot G, Neumann FJ, Petricevic M, Roffi M, Steg PG, Windecker S, Zamorano JL, Levine GN; ESC Scientific Document Group; ESC Committee for Practice Guidelines (CPG); ESC National Cardiac Societies. 2017 ESC focused update on dual antiplatelet therapy in coronary artery disease developed in collaboration with EACTS: The Task Force for dual antiplatelet therapy in coronary artery disease of the European Society of Cardiology (ESC) and of the European Association for Cardio-Thoracic Surgery (EACTS). Eur Heart J. 2018;39:213-60.

24. Task Force on Myocardial Revascularization of the European Society of Cardiology (ESC) and the European Association for Cardio-Thoracic Surgery (EACTS); European Association for Percutaneous Cardiovascular Interventions (EAPCI), Wijns W, Kolh P, Danchin N, Di Mario C, Falk V, Folliguet T, Garg S, Huber K, James S, Knuuti J, Lopez-Sendon J, Marco J, Menicanti L, Ostojic M, Piepoli MF, Pirlet C, Pomar JL, Reifart N, Ribichini FL, Schalij MJ, Sergeant P, Serruys PW, Silber S, Sousa Uva M, Taggart D. Guidelines on myocardial revascularization. Eur Heart J. 2010;31:2501-55.

25. Sianos G, Morel MA, Kappetein AP, Morice MC, Colombo A, Dawkins K, van den Brand M, Van Dyck N, Russell ME, Mohr FW, Serruys PW. The SYNTAX Score: an angiographic tool grading the complexity of coronary artery disease. EuroIntervention. 2005;1:219-27. 